\title{
Role of Health Care Professionals in Prevention of Hospital-Acquired Infections Caused By Carbapenemase Resistant Bacteria: Proactive Approach $S$ in General Hospital Ptuj.
}

\author{
Skender Veliư ${ }^{1}$, Dominika Vrbnjak ${ }^{2}$, Gabrijela Damevska Kaučič ${ }^{3}$, \\ Jasmina Kröpfl ${ }^{4}$
}

https://doi.org/10.32391/ajtes.v3i2.49

\begin{abstract}
Background: Health-related infections represent a very important complication of health care treatment. They are associated with high morbidity, mortality, disability and high costs of treatment, care and rehabilitation. The problem is its rising incidence, mainly as pathogens have developed various antimicrobial resistance mechanisms. Enterobacterias that excrete carbapenemases are a significant problem, especially as the treatment options for infections is increasingly limited. Several guidelines dictate measures to prevent their spread and control at different levels of health care. Implementation of guidelines in practice is not easy, as it requires a lot of knowledge, cooperation, consistency, material, environmental and human resources. The role of health care professionals is indispensable in this field. The aim of the article is to present the role of health care professionals in the prevention of Carbapenem-resistant Enterobacteriaceae (CRE) infections and proactive approach of General hospital Ptuj in preventing and controlling CRE.

Keywords: health-related infections, bacteria-resistant carbapenems, measures
\end{abstract}

*Corresponding author: Skender Veliu

$=凶$ E-mail: skender.veliu@gmail.com

${ }^{1}$ Surgery Service, General Hospital Dr. "Jože Potrč", Ptuj, Slovenia.

${ }^{2}$ University of Maribor Faculty of Health Sciences, Maribor, Slovenia.

IInternal Medicine Service, General Hospital Dr. "Jože Potrč" Ptuj, Slovenia.

${ }^{4}$ General Hospital Dr. "Jože Potrč" Ptuj, Slovenia. 


\section{Full Text}

\section{Introduction}

According to the World Health Organization, health-related infections are the most common unwanted event in health care worldwide (WHO, 2011). They are infections acquired in healthcare settings. These include hospital infections, infections in patients in nursing homes, in long-term care facilities, infections in patients requiring permanent outpatient care (dialysis, chemotherapy) or need permanent medical care at home. Hospital infections represent the most important proportion of health-related infections, especially as they usually affect the most vulnerable groups of patients (Lejko Zupanc, 2013). In the European Union, every 20th hospitalized patient has a hospital infection, which represents 4,1 million patients and 37,000 deaths associated with these infections on a yearly basis (ECDC, 2008). Hospital infections are not only financial costs, but they extend hospitalization, contribute to mortality and permanent disability of patients (Lejko Zupanc, 2013).

The proportion of patients with a hospital infection is significantly higher in Slovenian hospitals than in the European Union, which points to the exceptional severity of the problem. The dominant cause of hospital infection in Slovenia is Enterobacteriaceae (43.3\%). The most common cause of hospital infections in Slovenia and Europe is E. coli. In Slovenia, the most common causes of pneumonia and lower respiratory tract infection are Klebsiella spp. and P. aeruginosa $(20.7 \%)$, the most common causes of surgical wound infections are enterococci $(23.2 \%)$, the most common cause of urinary tract are E. coli infections (38.5\%) (Klavs et al., 2013).

A particular problem in the field of hospital infections is the spread of antimicrobial resistance. According to ECDC (2013) was more than half of Klebsiella spp. Resistant to cefalosporins of the third generation. In Slovenia, $41.9 \%$ of $\mathrm{P}$. aeruginosa strains are resistant to carbapenems, according to ECDC data, this proportion is lower in the European Union (31.8\%). According to ECDC, of all tested A. baumanii is $81.2 \%$ carbapenemresistant and can be found one in five isolates in Slovenia. These results are not encouraging and may indicate an increased use of carbapenems and an increase in antibiotic-resistant bacteria (Klavs et al., 2013). The increase of antibiotic resistance, especially betalactam antibiotics, is becoming an increasing problem at the global level. The consequences of infections caused by resistant bacterial strains are increased morbidity, mortality and increased costs of treatment (Hawkey, 2009).

In the last two decades of the 20th century, the attention of the medical profession and the pharmaceutical industry was directed mainly towards the problem of spreading resistant gram-positive bacteria, in particular MRSA and VRE (Nicasio et al., 2008). At the beginning of the 21st century, attention is paid to gram negative bacteria, increasing concern is caused by the occurrence of multiple resistant Enterobacteria (Adraševič et al., 2012). In Slovenia, we currently see the biggest problems in gram negative bacteria. According to all indicators, Slovenia is facing a threatening epidemic of growing resistance to gram negative bacteria (Lejko Zupanc, 2013). 


\section{Carbapenemase-producing Enterobacteriaceae}

Carbapenem are beta-lactam antibiotics that have the broadest spectrum of activity among all beta-lactams. They are used as the latest choice for the treatment of bacterial infections when other antibiotics, no longer have an effect (Papp Wallace et al., 2012). A problem is the spread of the antimicrobial resistance. In recent years, Enterobacteria have emerged with new antibiotic resistance mechanisms and treatment of infections is very limited (Livermore, 2012). The spreading of Enterobacteria that excrete carbapenemases presents a serious public health problem, and the extent of the problem varies greatly between countries (Canton et al., 2012). In Slovenia, we encounter individual cases (Štrumbelj et al., 2013). Many cases are related to importation from a foreign country such as Greece, Serbia, Croatia, Bosnia, Italy, Libya and India (Pirš et al., 2013). Carbapenem-resistant Enterobacteriaceae (CRE) infections are associated with poor outcomes and high mortality, high treatment costs (Hawkey, 2009; Magiorakos et al., 2017).

\section{Prevention of CRE and the role of health care professionals in preventing CRE}

In December 2015, the Slovenian National Commission for the Control of Hospital Infections adopted recommendations on measures to prevent the transmission of CRE. These recommendations focus primarily on the early detection of asymptomatic patients, strict contact isolation measures, the sensible use and control of antibiotic consumption and consultation with an infectious disease physician (NAKOBO, 2015).

In literature, there are several recommendations for preventing the spread of CRE. Literature shows that it is possible to completely avoid hospital expansion at early stages. It is also possible to act later, but with incomparably higher costs and lesser final success. Core infection prevention and control measures to minimize risk of spread of CRE within and between healthcare settings are: antimicrobial stewardship, environmental cleaning, equipment reprocessing, faecal and medical waste management, guidelines and processes, hand hygiene, infrastructure and capacity for patient accommodation, microbiological capacity, staff education, staffing, surveillance (Magiorakos et al., 2017). WHO (2017) prepared evidence-based recommendations on measures for the prevention and control of CRE, which consists of main eight recommendations: implementation of multimodal infection prevention and control strategies, importance of hand hygiene compliance for the control, surveillance of CRE infection and surveillance cultures for asymptomatic CRE colonization, contact precautions, patient isolation, environmental cleaning, surveillance cultures of the environment for CRE colonization/contamination and monitoring, auditing and feedback.

The European Expert Group proposes regional, national and international coordination (Štrumbelj, 2012). The key measures for successful prevention of the spread of CRE are primarily the early detection and the restriction of the spread with hospital hygiene measures and the screening of patients and their contacts (Akova et al., 2012; Monuz 
Price et al., 2013). Early detection of asymptomatic carriers is important. It is necessary to find also healthy carriers as they are an important reservoir of resistant bacteria (Štrumbelj, 2012). Risk factors for the occurrence of CRE are hospitalizations in health care institutions where CRE has been already present and contact with a patient with proven CRE. Surveillance samples include a rectal swab or a stool, which should be taken at the admission and then repeated after seven days. Patients with suspect on CRE should be in isolations until two surveillance samples are negative (NAKOBO, 2015). Contact isolation is recommended. Patients with CRE can be in cohort contact isolation, however, patients with other multiple resistant bacteria, such as MRSA, ESBL, VRE should not be in the same rooms. The contact isolation measures usually include the installation in a single room with own sanitary facilities (or cohort), the hygiene of the staff, patients and visitors, and the correct use of personal protective equipment. In case of contact with the patient or his immediate surroundings, we use protective gloves. A surgical mask is used only if the patient has a bacterium isolated in the respiratory system or in the aerosol forming processes. Medical devices must be separated and assigned only to a particular patient. We use disposable devices, which should be discarded. It is necessary to disinfect the patient's environment, using conventional cleaners and disinfectants. Particular attention should be paid to the cleaning and disinfection of sanitary facilities and on the final cleaning after the completion of the isolation measures (Pirš et al., 2013; NAKOBO, 2015). Contamination of surfaces contributes significantly to the colonization of patients., Terminal cleaning of hospital rooms with a disinfectant with hydrogen peroxide has been shown. As a successful measure to prevent the spread of bacteria that excrete carbapenems (Pirš et al., 2013). In our experience, disinfection with UV light it is extremely effective, which in addition to the efficacy also enables the patients to be quickly reinstalled into disinfected hospital rooms.

NAKOBO (2015) state that separate staff should take care for a colonized patient, if possible. In practice, it is often difficult to ensure that, as it is often difficult to ensure a sufficient number of insulation rooms. It is well known that the increase in the number of hospital infections is significantly affected by the lack of rooms and personnel (Clements et al., 2008). It is therefore important for nursing staff us to be aware of the seriousness of the problem. They should perform their tasks in accordance with the standards and professional guidelines. When there is a lack of separate rooms, we should try to find the safest solution for patients - implementation of isolation measures, separate from other patients. Pirš and others (2013) and NAKOBO (2015) state that inter-hospital and intra-hospital patient transfers are particular problem in preventing an outbreak. Health care staff should be warned that the patient is colonized or infected with CRE when transferred to other hospitals or other departments. The role of health care professionals is extremely important, as nurses should verbally and in writing inform other staff about the colonization. The patient's identification in the computer information system is also important (NAKOBO, 2015). 
Health care professionals can greatly contribute to reducing the spread of CRE. The consistent implementation of all standard measures to prevent the spread of healthcare-related infections are required. Hand cleansing is the primary action to reduce health-careassociated infection and crosstransmission of antimicrobial-resistant pathogens (Pittet et al., 2006). Healthcare professionals should follow WHO guidelines: My 5 Moments for Hand Hygiene approach. This approach recommends healthcare workers to clean their hands before touching a patient, before clean/aseptic procedures, after body fluid exposure/risk, after touching a patient, and after touching patient surroundings. It is important that health care professionals understand the importance of consistent hand hygiene and warn each other about possible deviations. Hygiene is also essential in patients and visitors. Patients need to wash and disinfect the hands after using the toilet and before leaving the hospital room. For visitors, the disinfection of hands is required before entering the hospital room and before contact with the patient and before leaving the hospital room (NAKOBO, 2015). Health care professionals should educate patients and visitors and about consistent hand hygiene.

The occurrence and spread of resistant bacteria are mainly associated with too frequent and incorrect use of antibiotics, therefore it is necessary to optimize the use of antimicrobial drugs in human medicine, veterinary and food industries with strict indications. Consistent measures must be taken to prevent and control health-related infections under national guidelines by including local epidemiological features. The education of healthcare professionals, patients, visitors and the public is a very important factor (Gorišek Miksić and Gorišek, 2017). Patients should be familiar with the problem of the emergence and spread of multiple resistant microorganisms, including CRE. Patients should be advised to take antibiotics as prescribed by physicians. Patients should not take antibiotics when this is not necessary and follow the prescribed instructions. In addition, hands should be washed regularly. We are all responsible for maintaining the effectiveness of antibiotics. Responsible use of antibiotics can help stop the spread of resistant bacteria and maintain the effectiveness of antibiotics for use in future generations (ECDC, 2016).

\section{CRE prevention in General hospital Ptuj}

General hospital Ptuj adopted proactive approach to problem solving, that is, pre-prepared readiness of resources and procedures, allowing early detection and limitation of the CRE problem. Identification of asymptomatic carriers is essential step, as experience shows that a lot of patients are not identified in early stages of hospitalization. In this area, the role of the Commission for the control of hospital infections is very important. Task of Commission is primarily to prepare professional guidelines and standards. As prevention of hospital-acquired infections are possible through strict adherence to evidence-based practices, it is important that the Commission prepare professional guidelines and standards based on current evidence such as WHO, ECDC guidelines and 
evidence from UpToDate. The next step is implementation of guidelines and standards into clinical practice and education of staff. Important role in implementation and education have physician for control of hospital infection and nurse for hospital infection. They prepare and provide theoretical education, support and advice in the implementation of guidelines in practice and monitor the practice in terms of constant surveillance. They also educate patients and their relatives about hospitalacquired infections and its prevention measures.

\section{References}

1. Akova, M., Daikos, G. L., Tzouvelekis, L. and Carmeli Y. (2012). Interventional strategies and current clinical experience with carbapenemase-producting Gram- negative bacteria. Clinal microbiology and infection, 18, 5, pp. 439-448.

2. Andrašević Tambić A., Jelić, M., Gužvinec, M., Butić, I. and Bukovski, S. (2012). Rezistentne enterobakterije u Hrvatskojuloga praćenja rezistencije na antibiotike na nacionalnoj razini. Croation journal of infection, 32, 2, pp. 45-52.

3. Canton, R., Akova, M. and Carmeli, Y. (2012). Rapid evolution and spread of carbapenemases among Enterobacteriaceae in Europe. Clinical microbiology and infection, 18, 5, pp. 413-431.

\section{Conclusion}

Health care professionals have an important role in controlling and preventing CRE. Everyone can contribute. Many health care professionals will need to change their thinking and awareness of the problem of health-related infections and the problem of the resistance of bacteria against antimicrobials. This is also the awareness of the necessity of daily, consistent implementation of all measures to prevent the spread of bacteria resistant to carbapenems, with an emphasis on hand hygiene.
4. Clements, A., Halton, K., Graves N., Pettit, A., Morton, A., Looke, D. et al. (2008). Overcrowding and understaffing in modern health- care systems: key determinants in meticillinresistant Staphylococcus aureus transmission. Lancet infectious diseases, 8, 7, pp. 427-434.

5. ECDC (2008). Annual Epidemiological Report on Communicable Diseases in Europe 2008. Stockholm: European Centre for Disease Prevention and Control. Available at: https:/ / ecdc.europa.eu/sites/p ortal/files/media/en/publicati ons/Publications/0812_SUR_A nnual_Epidemiological_Report_ 2008.pdf.

6. ECDC (2013). Point prevalence survery of health- care 
associated infections and antimicrobial use in European acute care hospitals. Stockholm: European Centre for Disease Prevention and Control. Available at: http:/ / ecdc.europa.eu/en/heal thtopics/Healthcareassociated_infections/pages7in dex.aspx.

7. ECDC (2016). Evropski dan antibiotikov, povzetek dejstev za splošno javnost. Available at: http:/ / ecdc.europa.eu/sl/eaad / antibiotics-getinformed/factsheets/Pages/ge neral-public.aspx.

8. Gorišek Miksić, N. and Gorišek Reberšek, J. (2017). Varnost pacientov in zdravstvenih delavcev pred okužbami povezanih $\mathrm{z}$ zdravstvom. In: Kraljić, S., Gorišek Reberšek, J. and Rijavec, V. (eds.). 26. posvet medicina, pravo in družba: Varnost pacienta in zdravstvenih delavcev. Maribor: Univerza v Mariboru, pp. 35-42.

9. Hawkey, PM. and Jones, AM. (2009). The changing epidemiology of resistance. Journal of antimicrobial chemotherapy, 64, pp. 3-10.

10. Klavs, I., Kolman, J., Lejko Zupanc, T., Kotnik-Kevorkijan, B., Korošec, A., Serdt, M. et al.. (2013). Prevalenca bolnišničnih okužb v slovenskih bolnišnicah za akutno oskrbo. Medicinski razgledi, 52, (Suppl 6), pp. 11-16.

11. Lejko Zupanc, T. (2013). Globalni pogled na problematiko okužb povezanih z zdravstvom.
Medicinski razgledi, 52, (Suppl 6), pp. 5-10.

12. Livermore, D. M. (2012). Current epidemiology and growing resistance of gram- negative pathogens. Korean Journal of Internal medicine, 27, pp. 128142.

13. Magiorakos, A. P., Burns, K., Rodríguez Baño, J., Borg, M., Daikos, G. et al. (2017). Infection prevention and control measures and tools for the prevention of entry of carbapenem-resistant Enterobacteriaceae into healthcare settings: guidance from the European Centre for Disease Prevention and Control. Antimicrobial Resistance \& Infection Control, 6:113.

14. Monuz Price, L. S., Poirel, L., Bonomo, R. A., Schwaber, M. J., Daikos, G. L., Cormican, M. et al. (2013). Clinical epidemiology of the global expansion of Klebsiella pneumoniae carbapenemases. Lancet infectious diseases, 13, 9, pp. 785-796.

15. NAKOBO. (2015). Ukrepi za preprečevanje prenosa bakterij, ki izločajo karbapenemaze. Priporočila UKC Ljubljana, sprejeta in priporočena s strani NAKOBO. Available at: http: www.mz.gov.si/fileadmin/mz. gov.si/.../NAKOBO_karbapene maze_3_.doc

16. Nicasio, AM., Pharm, D., Kuti, JL. And Nicolau, DP. (2008). The current state of multidugresistant gram negative bacilli in North

America. 
Pharmacotherapy, 28, 2, pp. 235249.

17. Papp Wallace, KM., Endimiani, A., Taracila, MA. And Bonomo, RA. (2011). Carbapenems: past, present, and future. Antimicrobical agents and chemotherapy, 55, 11, pp. 49434960.

18. Pirš, M., Cerar Kišek, T., Ambrožič Avguštin, J., Kolman, J., Seme, K. et al. (2013). Enterobakterije, ki izločajo karbapenemaze. Medicinski razgledi, 52, (Suppl 6), pp. 119127.

19. Pittet, D., Allegranzi, B., Sax, H., Dharan, S., Pessoa- Silva, CL., Donaldson, L. et al. (2006). Evidence - based model for hand transmission during patient care and the role of improved practices. Lancet infection diseases, 6, št. 10, str. 641-652.

20. Štrumbelj, I. (2012). Enterobakrterije s karbapenemazami-šepet pred viharjem. ISIS, junij 2012, pp. 4951.
21. Štrumbelj, I., Muelle Premru, M., Pirš, M. and Seme, K. (2013). Odpornost izbranih po Gramu negativnih bakterij- na pragu poantibiotične dobe. Medicinski razgledi, 5, (Suppl 6), pp. 99-108.

22. WHO. (2011). Report on the burden of endemic health care associated infection. Geneva: World Health Organization.

23. WHO. (2017). Guidelines for the prevention and control of carbapenem-resistant Enterobacteriaceae, Acinetobacter baumannii and Pseudomonas aeruginosa in health care facilities. Geneva: World Health Organization. Available at: https://apps.who.int/iris/bitst ream/handle/10665/259462/97 89241550178eng.pdf;jsessionid=D086CBA35 BEEC6590A5CB0B52988238D?se quence $=1$ 